\title{
Kognicja sądowoadministracyjna a odmowa powołania na stanowisko sędziego - kilka refleksji na tle postanowienia NSA z dnia 7 grudnia 2017 r. o sygn. akt I OSK 857/17
}

\section{Streszczenie}

W artykule wskazano najbardziej istotne argumenty podnoszone przez uczestników sporu dotyczącego możliwości kontroli przez sądy administracyjne postanowień Prezydenta RP o odmowie powołania na stanowisko sędziego oraz podjęto próbę dokonania ich merytorycznej oceny. Zdaniem autora odmowa powołania na stanowisko sędziowskie oraz niewyrażenie zgody na dalsze zajmowanie stanowiska sędziego przewidziane na gruncie znowelizowanych przepisów ustawy o SN powinny mieć charakter ściśle wyjątkowy i w zasadzie znajdować swoje uzasadnienie na płaszczyźnie konstytucyjnej, w czym należy upatrywać realizacji obowiązku Prezydenta czuwania nad przestrzeganiem Konstytucji. Zarówno jedno, jak i drugie rozstrzygnięcie powinno zawierać motywy, jakimi kierował się Prezydent, co czyniłoby ten akt, przy całej jego arbitralności, bardziej transparentnym. Jest to istotne nie tylko z punktu widzenia samego zainteresowanego, ale ma także ważny wymiar społeczny. Społeczeństwo ma bowiem prawo wiedzieć nie tylko, którzy kandydaci spełniający wymogi do objęcia urzędu sędziego i rekomendowani przez KRS nie zostali powołani przez Prezydenta, ale także jakie przyczyny legły u podstawy takiej decyzji Głowy Państwa.

Słowa kluczowe: prerogatywy prezydenckie, sąd administracyjny, prezydent

1 Dr hab. Michał Kowalski - Akademia Leona Koźmińskiego, Zakład Prawa Konstytucyjnego; e-mail,mkowalski@kozminski.edu.pl; ORCID: 0000-0002-8112-0922. 


\title{
Judicial administrative court, and refusal to appoint a judge - a few reflections on the background of the Supreme Administrative Court decision of 7 December 2017, Ref. I I OSK 857/17
}

\begin{abstract}
The paper indicates the most important arguments raised by the participants in the dispute concerning the possibility of control by the administrative courts of decisions of the President of the Republic of Poland on the refusal to appoint a judge and an attempt to make a substantive evaluation of them. In my opinion, the refusal to appoint a judge, as well as refusal to accept the judge's position under the amended Act on the Supreme Court (SC) should be strictly exceptional and in principle be justified at the constitutional level, which should be seen as the duty of the President to ensure compliance with the Constitution. Both of these resolutions should contain the motives of the President, which would make this act, with all its arbitrariness, more transparent. This is important not only from the point of view of the person concerned, but this also has an important social dimension. The public has the right to know, not only which candidates, who met the requirements for the appointment as a judge and were recommended by the National Council of the Judiciary of Poland (NCJ), were not appointed by the President, but also what reasons were at the heart of such a decision of the Head of State.
\end{abstract}

Keywords: presidential prerogatives, administrative court, president 


\section{Wprowadzenie}

Postanowieniem z dnia 22 czerwca 2016 r. wydanym na podstawie art. 179 Konstytucji RP2 Prezydent RP odmówił powołania trzech osób do pełnienia urzędu na stanowisku sędziego sądu rejonowego, okręgowego i apelacyjnego. Złożyli oni skargi do Wojewódzkiego Sądu Administracyjnego w Warszawie w trybie ustawy Prawo o postępowaniu przed sądami administracyjnymi ${ }^{3}$. W ocenie skarżących Prezydent RP nie mógł dowolnie korzystać z prerogatywy do powoływania sędziów, był związany przesłankami i procedurą nominacji, a także nie mógł oceniać kwalifikacji kandydatów na stanowiska sędziowskie i opiniować ich kandydatur. Ponadto skarżący podnosili, że wniosek Krajowej Rady Sądownictwa jest wiążący w sytuacji, w której kandydaci na stanowiska sędziowskie spełnili ustawowe wymagania i przeszli procedurę kwalifikacyjną oraz zostali przedstawieni przez KRS we wniosku o powołanie. Podnoszono, że brakowało konstytucyjnoprawnych przeszkód do ich nominacji, a brak uzasadnienia odmowy nominacji utrudnia weryfikację jej legalności i właściwego skorzystania Prezydenta RP z jego prerogatywy oraz pozbawia kandydatów możliwości poznania motywów odmowy. W tym świetle argumentowano, że wydane przez Prezydenta RP postanowienie jest aktem z zakresu administracji publicznej, który stwierdza uprawnienia wynikające z przepisów prawa, a zatem podlega kontroli sądowoadministracyjnej na podstawie art. $3 \S 2$ pkt 4 p.p.s.a.

W odpowiedzi na skargę Prezydent RP wniósł o jej odrzucenie ze względu na brak właściwości sądu administracyjnego w tej sprawie, a w razie przyjęcia skargi do rozpoznania o jej oddalenie, jako niezasadnej. Udział w tym postępowaniu zgłosili także Rzecznik Praw Obywatelskich oraz Helsińska Fundacja Praw Człowieka, popierający skargę kandydatów na stanowiska sędziowskie. Skarga została odrzucona przez WSA w Warszawie ${ }^{4}$, który powołał się m.in. na treść uchwały NSA z dnia 9 listopada 1998 r., w której przesądzono, że w zakresie, w jakim Prezydent

2 Na podstawie art. 179 Konstytucji Rzeczypospolitej Polskiej z dnia 2 kwietnia 1997 r. (Dz. U. Nr 78, poz. 483 ze zm. - powoływanej dalej jako Konstytucja RP) sędziowie są powoływani przez Prezydenta Rzeczypospolitej, na wniosek Krajowej Rady Sądownictwa, na czas nieoznaczony.

3 Ustawa z dnia 30 sierpnia 2002 r. Prawo o postępowaniu przed sądami administracyjnymi (t.j. Dz. U. z 2018 r. poz. 1302 - powoływana dalej jako p.p.s.a.).

4 Postanowienie WSA w Warszawie z dnia 29 grudnia 2016 r., sygn. akt II SA/Wa 1652/16, www. orzeczenia.nsa.gov.pl. 
RP działa jako Głowa Państwa Polskiego, symbolizując jego majestat oraz suwerenność, w pełni uznaniowa władza Państwa wykracza poza sferę działalności administracyjnej i nie stanowi wykonywania administracji publicznej, nie może więc podlegać kontroli sądu administracyjnego ${ }^{5}$. WSA przywołał również serię orzeczeń NSA z lat 2012-2013, w których ukształtowana została linia orzecznicza stwierdzająca brak kognicji sądowoadministracyjnej w sprawach skarg na postanowienia prezydenckie dotyczące odmowy powołania do pełnienia urzędu na stanowisku sędziego ${ }^{6}$.

Istota rozstrzygnięcia sądu pierwszej instancji sprowadzała się do przyjęcia, że postanowienie o odmowie powołania do pełnienia urzędu na stanowisku sędziego nie stanowi stosowania prawa w znaczeniu dosłownym i nie jest wykonywaniem administracji publicznej. Prezydent nie pełni w tym zakresie funkcji administracyjnej. Postanowienie o odmowie przyznania nominacji sędziowskiej stanowi realizację autonomicznych i uznaniowych uprawnień Prezydenta. Tak jak powołanie do pełnienia urzędu jest niezawisłą i dyskrecjonalną czynnością Prezydenta, w wyniku której głowa państwa nadaje konkretnej osobie uprawnienie do sprawowania władzy sądowniczej, tak i odmowa powołania do pełnienia urzędu na stanowisku sędziego stanowi element dyskrecjonalnej władzy Prezydenta. Postanowieniem z dnia 7 grudnia 2017 r. NSA oddalił wszystkie skargi kasacyjne wniesione w tej sprawie?

Niniejszy artykuł nie aspiruje do kompleksowego omówienia prawnego charakteru aktu prezydenta dotyczącego nominacji sędziowskich, jak również odmowy powołania na urząd sędziego. Zagadnienie to zostało dość dokładnie omówione w doktrynie prawa konstytucyjnego oraz orzecznictwie Trybunału Konstytucyjnego i sądów administracyjnych, dlatego poniżej postaram się wskazać najbardziej istotne argumenty podnoszone przez uczestników tego sporu, a także sformułować na tym tle własną ocenę tego zagadnienia. Na wstępnym etapie najbliższa jest mi koncepcja, zgodnie z którą w demokratycznym państwie prawnym powinno być zagwarantowane poddanie władczych rozstrzygnięć organu administracji publicznej, w tym także konstytucyjnego organu władzy wykonawczej, kontroli sądowej, w szczególności wówczas, gdy dotyczą one sfery praw i wolności zawartych w drugim rozdziale Konstytucji RP, takich jak zasada równego dostępu do

5 Uchwała Składu Siedmiu Sędziów NSA z dnia 9 listopada 1998 r., sygn. akt OPS 4/98, ONSA 1999 r., nr 1, poz. 6.

6 Postanowienia NSA: z dnia 30 marca 2013 r., sygn. akt I OSK 3129/12, z dnia 16 października 2012 r., sygn. akt I OSK 1785/12 i I OSK 1786/12, z dnia 17 października 2012 r., sygn. akt I OSK 1887/12 i I OSK 1889/12 z dnia 9 października 2012 r. sygn. akt I OSK 1883/12 - orzeczenia.nsa. gov.pl.

7 Postanowienie NSA z dnia 7 grudnia 2017 r., sygn. akt I OSK 857/17, www.orzeczenia.nsa.gov.pl. 
służby publicznej. Istotą tego unormowania jest zapewnienie równości szans w ubieganiu się o urzędy publiczne, bez gwarancji samego przyjęcia na dane stanowisko. Konieczne jest jednak wskazanie przejrzystych kryteriów wyboru kandydatów oraz ustanawianie stosownych gwarancji proceduralnych, także na drodze postępowania sądowego, pozwalających na weryfikację rozstrzygnięć wydawanych w tym zakresie ${ }^{8}$. Ewentualna kontrola sądowoadministracyjna tego rodzaju aktów wiązałaby się z koniecznością uzasadniania rozstrzygnięć odmownych w zakresie nominacji sędziowskiej. W sytuacji, gdy nie wiadomo, jakie przesłanki legły u podstaw takiej odmowy, nie może być mowy o jednolitych zasadach, ponieważ pozostawiono je dyskrecjonalnej władzy Głowy Państwa9.

\section{Charakter prawny prerogatywy prezydenckiej o powołaniu sędziów}

W obszarze tym występuje szereg niejednokrotnie skrajnych stanowisk ${ }^{10}$. Z jednej strony pojawiają się poglądy, w świetle których Konstytucja przyznaje Prezydentowi pełną swobodę w zakresie zarówno powołania sędziego, jak i odmowy powołania. Podjęte $w$ tym zakresie działania idą całkowicie na jego rachunek i podlegają jedynie odpowiedzialności na ogólnych warunkach ${ }^{11}$. Wskazują one, że Konstytucja nie nakłada na niego obowiązku uzasadnienia postanowienia, a przesłanki samego rozstrzygnięcia nie mają związku z unormowaniem ustawowym przewidującym procedurę powoływania sędziego. Tego rodzaju pogląd jest najbliższy stanowisku Głowy Państwa prezentowanemu w sprawie stanowiącej inspirację do powstania tego opracowania i jednocześnie stanowi element praktyki konstytucyjnej ostatnich lat ${ }^{12}$.

Także inne poglądy doktrynalne niewiele modyfikują to stanowisko. Uznają one, że Prezydent nie ma prawnego obowiązku pozytywnego rozpatrzenia wniosku KRS, zresztą sama istota wnioskowania sprowadza się do dwojakiej drogi załatwienia sprawy. W art. 179 Konstytucji mowa jest o wniosku, co należy łączyć $\mathrm{z}$ jego niewiążącym charakterem, nawet $\mathrm{w}$ sytuacji, gdy jest on koniecznym ele-

8 Wyrok TK 29 listopada 2007 r., sygn. akt SK 43/06, www.trybunal.gov.pl.

9 A. Szmyt, Wątpliwości wokót reform wymiaru sprawiedliwości, w: Ratio est anima legis. Księga Jubileuszowa ku czci Profesora Janusza Trzcińskiego, Warszawa 2007, s. 489.

10 T. Kuczyński, Z problematyki postępowania w sprawie powołania sędziego sądu administracyjnego, w: W stużbie dobru wspólnemu. Księga jubileuszowa dedykowana Profesorowi Januszowi Trzcińskiemu, red. R. Balicki, M. Masternak-Kubiak, Warszawa 2012, s. 448.

11 P. Sarnecki, Nota 11 Komentarza do art. 144 Konstytucji RP, Tom IV, Warszawa 2005.

12 B. Banaszak, Konstytucja Rzeczypospolitej Polskiej. Komentarz, Warszawa 2009, s. 795. 
mentem postępowania w tej sprawie. Roli Prezydenta RP nie można sprowadzać do czysto ceremonialnego zatwierdzenia pozytywnego zakończenia procedury prowadzonej przed KRS-em. Tego rodzaju stanowisko czasem wiąże się jednak z istotnym zastrzeżeniem, zgodnie z którym odmowa pozytywnego rozpatrzenia wniosku powinna być poprzedzona zgłoszeniem zastrzeżeń przez zasiadającego w Radzie przedstawiciela Prezydenta ${ }^{13}$. Generalnie zatem dominuje pogląd, zgodnie z którym próby przypisania Prezydentowi roli notariusza zatwierdzającego bezrefleksyjnie wniosek KRS-u zmierzają do zignorowania konstytucyjnych kompetencji tego organu i $\mathrm{w}$ istocie nadania osobistej prerogatywie czysto formalnego - związanego charakteru ${ }^{14}$.

Nie można przy tym ignorować argumentacji przemawiającej za brakiem prawnej możliwości zastosowania przez Prezydenta RP odmowy powołania na urząd sędziego kandydata wskazanego we wniosku KRS. Tego rodzaju stanowiska formułowane są jednak najczęściej w odwołaniu do ogólnych zasad systemowych, które powinny kształtować prawidłowe relacje między władzą sądowniczą a Głową Państwa, co warte podkreślenia, w warunkach należytej realizacji koncepcji państwa prawnego. Przekonujące $\mathrm{w}$ tym zakresie jest stanowisko uwzględniające wykładnię systemową Ustawy Zasadniczej, w świetle której prezydencka kompetencja do powoływania sędziów, o której mowa w art. 179 Konstytucji, została umieszczona wśród unormowań dotyczących gwarancji stabilności urzędu sędziego, co pozwala na racjonalne i bliższe powiązanie jej z gwarancjami trzeciej władzy niż uprawnieniami Prezydenta wywodzonymi jeszcze z czasów monarchii absolutnej, gdzie monarcha (król) był suwerenem i sprawował wszystkie rodzaje władzy. W ramach tej koncepcji zwraca się uwagę, że za przyjęciem modelu związania Prezydenta wnioskiem KRS o powołanie danej osoby na urząd sędziego przemawia okoliczność, że uprawnienie Prezydenta wynikające z art. 179 Konstytucji powinno być odczytywane przy uwzględnieniu szerszego wachlarza wartości konstytucyjnych, w szczególności takich jak niezależność i odrębność sądów od innych władz (art. 173 Konstytucji) oraz niezawisłość sędziów (art. 178 ust. 1), których treść stanowi integralny element prawa do sądu ${ }^{15}$. Obowiązkiem Prezydenta jest czuwanie nad przestrzeganiem Konstytucji oraz pełnienie funkcji arbitra w bieżących sporach politycznych, co powinno z niego czynić znajdującego się ponad politycznymi podziałami sojusznika władzy sądowniczej. W mojej ocenie

\footnotetext{
13 L. Garlicki, Komentarz do art. 179 Konstytucji RP, Tom IV, Warszawa 2005, s. 5.

14 W. Sokolewicz, Konstytucyjna regulacja władzy sądowniczej, w: Konstytucja, ustrój, system finansowy państwa. Księga pamiątkowa ku czci prof. Natalii Gail, Warszawa 1999, s. 174.

15 M. Szwast, Prawo do odpowiedniego ukształtowania ustroju i pozycji organów wymiaru sprawiedliwości, rozprawa doktorska obroniona w 2017 r. na WPiA UW, niepublikowana, s. 261 i nast.
} 
poszanowanie tego argumentu wymagałoby jednak przestrzegania wysokich standardów państwa prawnego i kultury prawnej. Sprowadzałoby się do odmowy powołania sędziego na urząd z uwagi na ważne przeszkody konstytucyjne i wymagałoby podania wyraźnych motywów, jakimi kierowała się Głowa Państwa ${ }^{16}$.

W świetle innego stanowiska Prezydent RP na podstawie art. 126 ust. 3 Konstytucji RP wykonuje swoje zadania w zakresie i na zasadach określonych w Konstytucji i ustawach, a także jest związany obowiązkiem działania na podstawie i w granicach prawa, a więc zasadą legalizmu wynikającą z art. 7 Ustawy Zasadniczej. W tym świetle regulacje prawne nie uprawniają Głowy Państwa do weryfikowania wniosków KRS, a zatem nie dają jej prawa do jego kwestionowania. Pogląd ten zakłada, że w Kancelarii Prezydenta nie działa specjalny wydział uprawniony do przeprowadzania ponownej weryfikacji akt osobowych kandydata na sędziego. Zgodnie z tą opinią Prezydent nie jest uprawniony do kwestionowania wniosku KRS i ma obowiązek powołania wysuniętego przez Radę kandydata ${ }^{17}$. W ramach tego modelu, który określam mianem zwiq̨zanego, przyjmuje się również, że Prezydent nie może odmówić powołania sędziego i jest obowiązany do współdziałania w tym zakresie z KRS. Unormowania przewidziane w art. $179 \mathrm{i}$ art. 144 ust. 3 pkt 17 Konstytucji nie mogą stanowić podstawy do wydania przez Prezydenta RP postanowienia o odmowie powołania sędziego. Wskazuje się w tym zakresie przede wszystkim na literalne brzmienie unormowania przewidzianego w art. 179 Konstytucji RP, zgodnie z którym sędziowie są powotywani przez Prezydenta Rzeczypospolitej, na wniosek KRS, na czas nieoznaczony, oraz samodzielność kompetencyjną KRS, a także ochronę niezależności władzy sądowniczej ${ }^{18}$.

W mojej ocenie trudno jednak podzielić tak radykalne stanowisko. Nie uwzględnia ono bowiem obowiązku czuwania przez Prezydenta nad przestrzeganiem Konstytucji i sprowadza jego rolę do bezrefleksyjnego - pozytywnego zatwierdzania wniosków KRS. Ułomność tego stanowiska wyraża się również w pozbawieniu procedury nominacyjnej tzw. zaworu bezpieczeństwa, pozwalającego - co warte podkreślenia - w wyjątkowych sytuacjach na zakwestionowanie przez Głowę Państwa niektórych kandydatur w sytuacji, gdy posiada on obiektywne informacje o konstytucyjnych przeszkodach do sprawowania urzędu przez daną osobę.

16 J. Ciapała, Charakter kompetencji Prezydenta RP. Uwagi w kontekście kompetencji w zakresie powotywania sędziów, „Przegląd Sejmowy” 2008, nr 4(87), s. 40-41.

17 R. Piotrowski, Sędziowie a władza wykonawcza. Wybrane problemy konstytucyjne, "Studia Iuridica” 2008, t. XLVIII, s. 212.

18 M Ziółkowski, Prerogatywa Prezydenta RP do powolywania sędziów (uwagi o art. 144 ust. 3 pkt 17 i art. 179 Konstytucji), „Przegląd Sejmowy” 2013, nr 1, s. 65. 
W literaturze pojawiają się także próby sformułowania stanowisk, będących $\mathrm{w}$ istocie wyrazem poszukiwania konsensusu pomiędzy sprowadzeniem roli Prezydenta RP do uprawnień czysto ceremonialnych w procedurze powoływania sędziów, a odnajdywaniem w tej roli uprawnień władczych, wynikających z kompetencyjnego charakteru prerogatyw ${ }^{19}$. Wyrazem tego rodzaju dążeń jest m.in. stanowisko, zgodnie z którym Prezydent mógłby ocenić wniosek KRS negatywnie jedynie wówczas, gdy przemawiają za tym nadzwyczajne okoliczności, które osobiście łączę z obowiązkiem czuwania nad przestrzeganiem Ustawy Zasadniczej. Wówczas mógłby je zawrzeć w pisemnych zastrzeżeniach i zwrócić akta awansowe do KRS-u, w celu ponownego rozpatrzenia sprawy. Tego rodzaju rozwiązanie przewiduje ustawa o $\mathrm{KRS}^{20}$, która w art. 45 ust. 2 i 3 wskazuje, że w przypadku ujawnienia nowych okoliczności dotyczących osoby wskazanej we wniosku o powołanie do pełnienia urzędu sędziego albo asesora sądowego, przedstawionym Prezydentowi RP, z wnioskiem o ponowne rozpatrzenie sprawy może wystąpić również Prezydent. O ponownym rozpatrzeniu albo jego odmowie Rada rozstrzyga w drodze uchwały. W orzecznictwie SN przyjmuje się przy tym, że nowe okoliczności, o których mowa w tym unormowaniu, to zarówno te, które istniały w trakcie poprzedniego rozpoznawania sprawy, lecz nie były znane tak Radzie i uczestnikom postępowania, jak i okoliczności zaistniałe już po zakończeniu postępowania, a dotyczące istoty sprawy i mogące mieć wpływ na sposób jej rozstrzygnięcia ${ }^{21}$. W świetle tego unormowania oczywiste jest, że Prezydent posiada uprawnienie do merytorycznej oceny wniosku nominacyjnego. Zgodnie jednak z poglądami wyrażonymi w literaturze, nieprzychylenie się przez Radę do zastrzeżeń Prezydenta i ponowne skierowanie do niego wniosku o powołanie sędziego byłoby w takiej sytuacji dla Głowy Państwa bezwzględnie wiążące ${ }^{22}$. Z tym ostatnim twierdzeniem także trudno się zgodzić, ponieważ w mojej ocenie Prezydent, któremu przyznano kompetencję do powoływania sędziów, ma prawo do odmiennej oceny faktów lub okoliczności stanowiących przeszkodę do wydania pozytywnego aktu nominacyjnego, w takiej sytuacji powinny one jednak zostać uzewnętrznione w pisemnych motywach postanowienia.

Stanowisko w tym przedmiocie zajął także Trybunał Konstytucyjny, choć ze względów formalnych wypowiedź ta miała ograniczony zakres merytoryczny.

19 W. Brzozowski, Niezależność konstytucyjnego organu państwa i jej ochrona, Warszawa 2016, s. 131-132.

20 Ustawa z dnia 12 maja 2011 r. o Krajowej Radzie Sądownictwa (tekst jedn. Dz.U. z 2019 r. poz. 84 - powołana dalej jako ustawa o KRS).

21 Wyrok SN z dnia 9 sierpnia 2012 r., sygn. akt III KRS 18/12, www.legalis.pl.

22 T. Ereciński, J. Gudowski, J. Iwulski, Prawo o ustroju sądów powszechnych, Ustawa o Krajowej Radzie Sądownictwa. Komentarz, red. J. Gudowski, Warszawa 2010, s. 187. 
Trybunal, rozpoznając wniosek Pierwszego Prezesa SN o rozstrzygnięcie sporu kompetencyjnego pomiędzy Prezydentem RP i KRS w zakresie kompetencji do opiniowania kandydatów na stanowiska sędziowskie, umorzył postępowanie ze względu na niedopuszczalność wydania wyroku. TK wskazał jednak, że Prezydent nie może dokonywać czynności składających się na wykonywanie kompetencji opiniowania kandydatów do pełnienia urzędu sędziowskiego przyznanej Radzie. Wskazał również, że „W przy padku Prezydenta jego akt przybiera postać postanowienia w sprawie skorzystania (lub nieskorzystania) z kompetencji powoływania na urząd sędziego. Nie bez znaczenia dla sposobu funkcjonowania Prezydenta w tym zakresie pozostaje okoliczność, że w świetle art. 144 ust. 3 pkt 17 Konstytucji kompetencja Prezydenta określona w art. 179 Konstytucji traktowana jest jako uprawnienie osobiste (prerogatywa) Prezydenta (a zarazem: sfera jego wyłącznej gestii i odpowiedzialności) oraz że Prezydent jest najwyższym przedstawicielem RP (art. 126 ust. 1 Konstytucji). Nadto okolicznością istotną pozostaje brak określenia cech aktu urzędowego powołania na stanowisko sędziowskie [...], a konstytucyjna forma postanowienia, ogłaszanego w Monitorze Polskim sprawia, że zewnętrzna postać aktu urzędowego Prezydenta nie obejmuje uzasadnienia podjętej decyzji personalnej"23.

Stanowisko zawarte w orzeczeniu TK może podlegać różnym interpretacjom. Niemniej jednak, pomimo formalnego charakteru rozstrzygnięcia, w mojej ocenie wskazał on na postanowienie Prezydenta w sprawie skorzystania lub nieskorzystania z kompetencji powoływania na urząd sędziego, co - jak się wydaje - przełamuje wątpliwości co do czysto ceremonialnego (związanego) charakteru tego aktu, a także wskazał wyraźnie, że forma tego aktu nie obejmuje uzasadnienia decyzji personalnej. Wydaje się więc, że również w ocenie Trybunału nie została całkowicie wyłączona decyzyjność Prezydenta RP w tym zakresie ${ }^{24}$. Umorzone zostało także postępowanie wywołane skargą konstytucyjną na art. $55 \S 1$ ustawy Prawo o ustroju sądów powszechnych ${ }^{25}$, rozumiany w ten sposób, że dopuszcza możliwość niepowołana sędziego przez Prezydenta pomimo wniosku KRS, w szczególności na podstawie bliżej nieokreślonych kryteriów oraz bez podania uzasadnienia. Trybunał uznał bowiem, że zarzuty skarżących dotyczą mechanizmu konstytucyjnego, a także nie została w tej sprawie wyczerpana przysługująca droga praw$n \mathrm{a}^{26}$. Merytoryczne orzeczenie zostało natomiast wydane na kanwie kwestiono-

Postanowienie TK z dnia 23 czerwca 2008 r., sygn. akt Kpt 1/08, www.trybunal.gov.pl.

Por. M. Ziólkowski, Prerogatywa Prezydenta RP..., s. 61.

Ustawa z dnia 27 lipca 2001 r. Prawo o ustroju sądów powszechnych (t.j. Dz. U. z 2019 r. poz. 52 ze zm. - powoływana dalej jako p.u.s.p).

Postanowienie TK z dnia 19 czerwca 2012 r., sygn. akt SK 37/08, www.trybunal.gov.pl. 
wania zakreślenia Prezydentowi RP przez ustawę p.u.s.p. miesięcznego terminu na powołanie sędziów ${ }^{27}$. Unormowanie to zostało uznane za niezgodne z art. 179 i art. 2 Konstytucji RP. Trybunał potwierdził w nim m.in., że kompetencja w zakresie powoływania sędziów pozostaje w sferze wyłącznej gestii i odpowiedzialności Prezydenta, aczkolwiek nie znaczy to, że może on działać całkowicie dowolnie, ponieważ wiążą go zasady i wartości wyrażone w Konstytucji ${ }^{28}$.

Podmioty kwestionujące stanowisko zawarte w postanowieniu WSA w Warszawie odrzucającym skargę na akt Prezydenta RP formułowały w tym zakresie zdecydowanie dalej idące stanowisko niż większość wspomnianych poglądów doktrynalnych i orzeczniczych. Argumentowały one, że osobom aspirującym do stanowiska sędziego przysługiwało prawo podmiotowe w tym zakresie, zgodnie z wnioskiem KRS, zaś Prezydent RP nie miał podstawy do wydania postanowienia o odmowie nominacji. Nie miał on przy tym kompetencji do oceny kwalifikacji kandydatów na stanowiska sędziowskie, opiniowania oraz rozpatrywania ich kandydatur - kompetencje te należą bowiem do innych podmiotów i organów, zaś decyzja o skorzystaniu z prerogatywy nie może być podejmowana w sposób dowolny.

NSA nie podzielił jednak tych argumentów, wskazując, że Prezydent RP nie jest organem administracji publicznej w rozumieniu przepisów ogólnego postępowania administracyjnego. Konstytucja zalicza go wprawdzie do organów władzy wykonawczej, ale nie do struktury administracji ${ }^{29}$. Pojęcie władzy wykonawczej jest szersze od pojęcia administracji publicznej i zawiera w sobie także prowadzenie polityki państwa, nadawanie zasadniczych kierunków działania, kompetencje kontrolne i nadzorcze. Kompetencja w zakresie powołania do pełnienia urzędu na stanowisku sędziego, jak i odmowy takiego powołania, jest specjalną prerogatywą Prezydenta RP jako Głowy Państwa. Jest to czynność niezawisła i dyskrecjonalna, która nie podlega kontroli sądu administracyjnego ${ }^{30}$.

Sąd kasacyjny negatywnie odniósł się także do argumentu, że Prezydent RP występuje jako organ administracji publicznej w innych sprawach, np. w sprawach z zakresu dostępu do informacji publicznej. Wskazał przy tym, że podmioty zobowiązane do udostępnienia informacji publicznej nie są tożsame z organami admi-

27 Zgodnie z niekonstytucyjnym art. 55 § 1 p.u.s.p., sędziów sądów powszechnych do pełnienia urzędu na stanowisku sędziowskim powołuje Prezydent Rzeczypospolitej Polskiej, na wniosek Krajowej Rady Sądownictwa, w terminie miesiąca od dnia przesłania tego wniosku.

28 Wyrok TK z dnia 5 czerwca 2012 r., sygn. akt K 18/09, www.trybunal.gov.pl oraz prawo.sejm.gov.pl ze zdaniem odrębnym P. Tulei.

29 Z. Niewiadomski, Pojęcie administracji publicznej, w: Instytucje prawa administracyjnego, red. R. Hauser, Z. Niewiadomski, A. Wróbel, Wydawnictwo C.H. Beck, Warszawa 2015, Tom 1, s. 3 i nast.

30 Postanowienie NSA z dnia 16 października 2012 r., sygn. akt I OSK 1887/12, www.orzeczenia. nsa.gov.pl. 
nistracji publicznej. Sprawy z zakresu dostępu do informacji publicznej dotyczą realizacji prawa obywatelskiego wynikającego z art. 61 Konstytucji $\mathrm{RP}^{31}$, a nie ustrojowych rozstrzygnięć Prezydenta. Prezydent jako organ w postępowaniach z zakresu dostępu do informacji publicznej nie korzysta jednak ze swoich prerogatyw. W mojej ocenie jednak odmowa mianowania na stanowisko sędziowskie dotyczy także obywatelskiego prawa podmiotowego, o którym mowa w art. 60 Konstytucji, w świetle którego obywatele polscy korzystający z pełni praw publicznych mają prawo dostępu do służby publicznej na jednakowych zasadach. W takim znaczeniu akt prezydenta nie stanowi jedynie ustrojowego rozstrzygnięcia Głowy Państwa, ale rozstrzyga o publicznym - konstytucyjnie umocowanym - prawie podmiotowym, co następuje jednak $w$ drodze zastosowania uprawnienia będącego prezydencką prerogatywą, a to z kolei istotnie odróżnia tę sprawę od spraw z zakresu dostępu do informacji publicznej ${ }^{32}$.

Dodatkowo - co warte odnotowania - pomiędzy Prezydentem a osobą, co do której został przedstawiony przez KRS wniosek o powołanie sędziego, nie występuje stosunek administracyjnoprawny ${ }^{33}$. Tego rodzaju stosunku nie ma także pomiędzy KRS a Prezydentem RP. Akty wydawane przez Radę (w przedmiocie przedstawienia wniosku o powołanie sędziego) oraz przez Prezydenta (postanowienie o powołaniu sędziego) są wykonaniem odmiennych kompetencji obu konstytucyjnych organów. Prezydent nie jest więc związany wnioskiem Krajowej Rady Sądownictwa. Wśród przewidzianych na gruncie art. 144 ust. 3 Konstytucji prerogatyw przewidziano szereg uprawnień kreacyjnych znajdujących zastosowanie w odniesieniu do kształtowania składu osobowego najważniejszych organów władzy sądowniczej, w tym również wyłączną kompetencję do powoływania sędziów. Akt Prezydenta poprzedzony działaniami mającymi na celu wyłonienie kandydata przez KRS nie oznacza, że działaniu Prezydenta można przypisać cechy administracyjnoprawne. Również to, że w Kancelarii Prezydenta RP podejmowane są czynności o charakterze wyjaśniającym, nie oznacza, że są to czynności

31 Na podstawie art. 61 ust. 1 Konstytucji RP, obywatel ma prawo do uzyskiwania informacji o działalności organów władzy publicznej oraz osób pełniących funkcje publiczne. Prawo to obejmuje również uzyskiwanie informacji o działalności organów samorządu gospodarczego i zawodowego, a także innych osób oraz jednostek organizacyjnych w zakresie, w jakim wykonują one zadania władzy publicznej i gospodarują mieniem komunalnym lub majątkiem Skarbu Państwa.

32 Na ten temat szerzej: M. Kowalski, Nadużycie prawa do informacji publicznej, ZNSA z 2016 r., nr 2(65), s. 50.

33 R. Hauser, Stosunek administracyjnoprawny, w: Instytucje prawa administracyjnego, red. R. Hauser, Z. Niewiadomski, A. Wróbel, Tom 1, s. 194 i nast. 
z zakresu postępowania administracyjnego, podejmowane $\mathrm{w}$ celu załatwienia sprawy administracyjnej ${ }^{34}$.

Zmierzając do sformułowania ogólnego stanowiska w tym zakresie, przyjmuję, że Prezydent RP może nie uwzględnić wniosku KRS w zakresie nominacji sędziowskiej. W takiej sytuacji, na podstawie art. 45 ustawy o KRS, występuje do Rady z wnioskiem o ponowne rozpatrzenie sprawy, podając jednocześnie, jakie okoliczności - $\mathrm{w}$ jego ocenie - stanowią przeszkodę do uzyskania przez kandydata nominacji sędziowskiej. W sytuacji ponownego skierowania przez KRS wniosku o nominację tej samej osoby, Prezydent ma jednak prawo do własnej oceny okoliczności sprawy, choć w przy padku odmowy nominacji konieczne jest, z uwagi na zasady państwa prawnego, podanie pisemnych motywów rozstrzygnięcia. Przyjęcie odwrotnego rozwiązania i uznanie, że Prezydent jest bezwzględnie związany wnioskiem KRS, prowadziłoby do sprowadzenia roli Głowy Państwa do podjęcia jedynie działań o charakterze ceremonialnym, co nie licuje z jego pozycją ustrojową w polskim systemie konstytucyjnym ${ }^{35}$.

Podobne rozwiązanie znalazło zastosowanie w ramach procedury przewidzianej w ustawie o Sądzie Najwyższym ${ }^{36}$. Zgodnie z przewidzianym w niej unormowaniem, Prezydent RP, przed wyrażeniem zgody na dalsze zajmowanie stanowiska sędziego SN lub NSA, zasięga opinii KRS. Rada przekazuje Prezydentowi RP opinię w terminie 30 dni od dnia wystąpienia przez Prezydenta o przedstawienie tej opinii. W przypadku nieprzekazania opinii w tym terminie uznaje się, że Rada wydała opinię pozytywną. Sporządzając opinię, KRS bierze pod uwagę interes wymiaru sprawiedliwości lub ważny interes społeczny, w szczególności racjonalne wykorzystanie kadr sędziowskich lub potrzeby wynikające z obciążenia zadaniami poszczególnych izb. W tym przypadku opinia KRS także nie ma wiążącego charakteru. Zgodnie zaś z odpowiednio stosowanym art. 39 ustawy o SN datę przejścia sędziego NSA w stan spoczynku albo przeniesienia sędziego SN i NSA w stan spoczynku stwierdza Prezydent RP ${ }^{37}$. Stanowisko Prezydenta w tej kwestii jest takie

34 M. Kowalski, Terminy w postępowaniu administracyjnymi i sądowoadministracyjnym, Wrocław 2013, s. 19 i nast.

35 K. Weitz, Komentarz do art. 179 Konstytucji RP, w: Konstytucja RP, Tom II, red. M. Safjan, L. Bosek, Warszawa 2016, s. 1045 i powołana tam literatura.

36 Ustawa z dnia 8 grudnia 2017 r. o Sądzie Najwyższym (Dz. U. z 2018 r. poz. 5 ze zm. - dalej jako ustawa o SN).

37 Negatywnie o reformie KRS-u: L. Garlicki, Niezależność sądownictwa-powoływanie sędziów - nadrzędność konstytucji (kilka uwag nad ewolucją orzecznictwa Sądu Najwyższego w Indiach), w: Aktualne problemy konstytucji. Księga jubileuszowa z okazji 40-lecia pracy naukowej Profesora Bogusława Banaszaka, red. H. Babiuch, P. Kapusta, J. Michalska, Legnica 2017, s. 139. Na ten temat zobacz także: A Łabno, Krajowa Rada Sądownictwa. Pozycja ustrojowa i możliwości reformy. Wybrane zagadnienia, w: Aktualne problemy konstytucji. Księga jubileuszowa..., s. 438. 
samo jak w przypadku odmowy powołania lub awansu na wyższe stanowisko sędziowskie, a więc postanowienie Prezydenta RP w sprawie wyrażenia lub braku zgody na dalsze zajmowanie stanowiska sędziego nie wymaga kontrasygnaty Prezesa Rady Ministrów, ponieważ mieści się w zakresie prerogatywy polegającej na powoływaniu sędziów. W ocenie Prezydenta postanowienie, z tych samych przyczyn, nie wymaga uzasadnienia ${ }^{38}$.

W mojej ocenie, zarówno odmowa powołania na stanowisko sędziowskie, jak i niewyrażenie zgody na dalsze zajmowanie stanowiska sędziego powinny mieć charakter wyjątkowy i w zasadzie znajdować swoje uzasadnienie na płaszczyźnie konstytucyjnej. Uzasadnienie zawierające motywy odmowy powołania na stanowisko sędziego lub braku zgody na dalsze orzekanie nie tylko jest istotne z punktu widzenia samego zainteresowanego, ale ma także wymiar społeczny. Społeczeństwo ma bowiem prawo wiedzieć nie tylko, którzy kandydaci spełniający wymogi do objęcia urzędu sędziego i rekomendowani przez KRS nie zostali powołani przez Prezydenta, ale także jakie przyczyny legły u podstawy takiej decyzji Głowy Państwa. Dodatkowo postanowienie pozbawione uzasadnienia wpływa na takie wartości jak godność osobista, cześć i dobre imię. Pozbawiona motywów decyzja Prezydenta może być i w rzeczywistości często jest kojarzona z wystąpieniem jakichś uchybień w życiorysie osobistym lub zawodowym kandydata na sędziego, co może przekładać się w pewnym sensie na stygmatyzację społeczną i zawodową takiej osoby ${ }^{39}$. W świetle aktualnego unormowania konstytucyjnego wydaje się co prawda, że Prezydent nie ma obowiązku uzasadniania aktów odmawiających powołania na stanowisko sędziego i odmowy przedłużenia możliwości orzekania przez sędziów, ale zmiana zwyczaju konstytucyjnego w tym zakresie na pewno zostałaby dobrze przyjęta zarówno w środowisku prawniczym, jak i w odbiorze społecznym oraz mogłaby stanowić wyraz dobrej woli i praktyki konstytucyjnej.

W mojej ocenie docelowym rozwiązaniem w tym zakresie powinna być koncepcja zakładająca możliwość odmowy przez Prezydenta powołania sędziego, lecz powinien on w takiej sytuacji podać jasne motywy swojego postanowienia, a ono samo powinno podlegać kontroli sądu administracyjnego. W tym kontekście warto przytoczyć jeden z wyroków Najwyższego Sądu Administracyjnego w Brnie ${ }^{40}$, dotyczący kognicji sądowoadministracyjnej odnośnie do kontroli legalności aktów Prezydenta Republiki Czeskiej w przedmiocie odmowy powołania na stanowisko sędziowskie. Sprawa dotyczyła skarżącego, który był doktorem prawa, wykonywał

38 Komunikat w sprawie oświadczeń sędziów o woli dalszego zajmowania stanowiska w Sądzie Najwyższym i Naczelnym Sądzie Administracyjnym z dnia 11 września 2018 r., www.prezydent.pl.

39 T. Kuczyński, Z problematyki postępowania..., s. 452.

40 Wyrok Nejoyšši Správni Soud w Brnie z dnia 27 kwietnia 2006 r., sygn. akt 4 Aps 3/2005. 
pracę naukowo-dydaktyczną, a następnie złożył z wynikiem wzorowym egzamin sędziowski i został przedstawiony przez Rząd Republiki Czeskiej we wniosku do Prezydenta o mianowanie na urząd sędziego. W dniu 15 marca 2005 r. skarżący otrzymał od Ministra Sprawiedliwości Republiki Czeskiej pismo, w którym został poinformowany, że Prezydent odmówił uwzględnienia wniosku o nominację sędziowską z powodu wieku kandydata. Pismo to stało się przedmiotem skargi do Sądu Grodzkiego w Pradze ${ }^{41}$, który jednak ją odrzucił, wskazując, że akt Prezydenta Republiki Czeskiej, w zakresie mianowania danej osoby do pełnienia funkcji na stanowisku sędziego lub odmowy takiej nominacji, nie stanowi rozstrzygnięcia o publicznych prawach podmiotowych jego adresata. Postępowanie, w którym dokonuje się wyboru kandydatów na sędziów i przedstawia Prezydentowi Republiki Czeskiej wnioski nominacyjne, nie zostało bowiem skonstruowane na zasadzie rozstrzygania o publicznym prawie podmiotowym, a na zasadzie wyboru określonych kandydatur. $Z$ tego powodu czeski sąd administracyjny pierwszej instancji uznał się za niewłaściwy w zakresie kontroli legalności tego rodzaju czynności. W uzasadnieniu wskazywano, że żaden akt rangi ustawowej nie przyznaje skarżącemu prawa do żądania bycia mianowanym na urząd sędziego, a skoro na gruncie rozpatrywanej sprawy nie może być wywiedzione uprawnienie wynikające zarówno z materialnego, jak i prawa procesowego, to sprawa ta nie należy do kompetencji sądu administracyjnego ${ }^{42}$.

Od tego orzeczenia skarżący wniósł skargę kasacyjną (kasační stížnost) do Najwyższego Sądu Administracyjnego w Brnie, który uchylił postanowienie Sądu Grodzkiego w Pradze i przekazał sprawę do ponownego rozpatrzenia. Na wstępie czeski NSA zaznaczył, że spór prawny na gruncie rozpatrywanej sprawy dotyczy nie tego, jaki jest sposób postępowania z wnioskiem o powołanie na urząd sędziego, a tego, czy sprawa należy do kognicji sądowoadministracyjnej. W dalszej części uzasadnienia wskazywano m.in., że rozstrzygnięcie Prezydenta, w ramach którego realizuje on swoje uprawnienia do powoływania sędziego, odpowiada istocie i formie działań administracyjnych. Prezydent Republiki występuje w tym przypadku jako organ administracji publicznej, a tego rodzaju rozstrzygnięciom, jak

41 W Czechach występuje model hybrydowy (mieszany), w którym sprawy administracyjne w pierwszej instancji rozpatrują sądy powszechne - sądy okręgowe (Krajské Soudy) oraz Sąd Grodzki w Pradze (Městský soud v Praze), nad którymi nadzór judykacyjny w ramach rozpatrywanych skarg kasacyjnych (kasačni stǐžnost) sprawuje wyspecjalizowany sąd administracyjny - Nejvy̌šsi Správni Soud w Brnie.

42 J. Sułkowski, Dokumenty - wyrok Najwyższego Sądu Administracyjnego w Brnie z dnia 27 kwietnia 2006 r., sygn. akt 4 Aps 3/2005 dotyczący kognicji sądowoadministracyjnej odnośnie do kontroli legalności aktów Prezydenta Republiki Czeskiej w przedmiocie odmowy powotania na stanowisko sędziowskie, "Przegląd Sejmowy" 2008, nr 4, s. 304 i nast. Zob. też J. Sułkowski, Uprawnienia Prezydenta RP do powotywania sędziów, „Przegląd Sejmowy” 2008, nr 4, s. 46 i nast. 
i dalszym czynnościom podejmowanym przy wykonywaniu jego uprawnienia w zakresie powoływania sędziów w demokratycznym państwie prawnym, obligatoryjnie musi przysługiwać stosowna ochrona prawna.

Poza powyższym wskazano, że sądy administracyjne nie mogą kontrolować działań Prezydenta w ramach procedury nominacji sędziowskich jako takich. Ich ocenie może jednak podlegać spełnienie ustawowych przesłanek koniecznych do wykonywania funkcji sędziego. Zdaniem Sądu nie można bowiem rezygnować z funkcji sądownictwa administracyjnego, która w związku z ochroną legalności rozstrzygnięć organów administracji zmierza do całkowitego ukształtowania władzy wykonawczej (której częścią jest Prezydent) w zgodności z obecnymi zasadami demokratycznego państwa prawa i dlatego trzeba przedmiotową sprawę w odpowiedni sposób rozstrzygnąć. W konkluzji podniesiono, że w sytuacji, gdy do kompetencji sądowoadministracyjnej nie należy prawo do pociągania Prezydenta do odpowiedzialności, ale należy do niej kontrola jego aktów, wyrok sądu administracyjnego może oznaczać jedynie moralny apel, by przy pełnieniu swej funkcji kierował się względami kultury prawnej.

W kolejnym wyroku ${ }^{43}$ Nejvyšši Správni Soud w Brnie stwierdził, że kompetencja Prezydenta w zakresie powoływania sędziów musi spełniać wymogi stawiane organom administracji publicznej. Należy do nich w szczególności uwzględnienie ustawowych przesłanek przewidzianych dla urzędu sędziego. Sąd podkreślił, że niedopuszczalne jest stwarzanie przez Prezydenta dodatkowych kryteriów niewynikających z ustawy. Dodał jednak, że jeżeli Prezydent dojdzie do wniosku, że doświadczenie i cechy moralne nie dają gwarancji należytego pełnienia urzędu sędziego, ma nie tylko prawo, lecz także obowiązek odmowy powołania na stanowisko ${ }^{44}$. W wyroku z tym wskazano również, że z zasady państwa prawnego, zasady legalizmu oraz zakazu samowoli wynika obowiązek przedstawienia odpowiednich motywów, jakimi kierowała się Głowa Państwa, odmawiając powołania na urząd sędziego ${ }^{45}$.

Odnośnie do wspomnianego wyroku Najwyższego Sądu Administracyjnego w Brnie należy jednak zauważyć, że zarówno pozycja ustrojowa Prezydenta Republiki Czeskiej, jak i jego uprawnienia w zakresie powoływania sędziów, są skonstruowane odmiennie od unormowania przewidzianego w Konstytucji RP.

43 Wyrok Najwyższego Sądu Administracyjnego w Brnie z dnia 21 maja 2008 r., sygn. akt 4 Ans 9/2007 r. (publ. pod nr Dz.U.Cz z 2008 r. NSS).

44 P. Molek, Relacje między prezydentem, a władzą sądowniczą w republice parlamentarnej, w: Sądownictwo administracyjne w Polsce i Czechach (wybrane zagadnienia omawiane w ramach polsko-czeskiej wspótpracy sędziów sądów administracyjnych), Warszawa 2018, s. 43.

45 A. Roztocil, Orzecznictwo dotyczq̨ce aktów prezydenta w zakresie powotywania i odwotywania sędziów oraz sędziów funkcyjnych, w: Sądownictwo administracyjne w..., s. 54. 
Czeska Konstytucja ${ }^{46}$ przewidywała wówczas co prawda, że Prezydent Republiki jest głową państwa, niemniej jednak wybierał go Parlament na wspólnym posiedzeniu obu izb, co jest cechą charakterystyczną modelu parlamentarno-gabinetowego (art. 54 ust. 1 i 2 Konstytucji Republiki Czeskiej) ${ }^{47}$. Należy jednak zaznaczyć, że zmiana Konstytucji ${ }^{48}$ w 2012 r. zakresie sposobu wyboru Prezydenta Republiki nie zmieniła tego, że czeski NSA (NSS) nadal kontroluje postanowienia Prezydenta Czech. Już po 2013 r., kiedy Prezydent był wybierany w wyborach powszechnych, miał miejsce przypadek odmowy mianowania profesorów wyższych uczelni. Zainteresowani zaskarżyli ten akt do sądu administracyjnego pierwszej instancji, który wydał wyrok nakazujący ich mianowanie. Prezydent zaskarżył go do NSA (NSS) w Brnie, jednak następnie wycofał skargę kasacyjną, ponieważ obawiał się niepomyślnego dla siebie rozstrzygnięcia. Po uprawomocnieniu się tego orzeczenia Prezydent ponownie odmówił przyznania tytułów profesorskich, a zainteresowani ponownie złożyli skargi do sądu administracyjnego w Pradze. Sprawa nie została jak dotąd ostatecznie zakończona, niemniej jednak przesądzono kognicję sądowoadministracyjną $\mathrm{w}$ tego typu sprawach ${ }^{49}$.

Należy przy tym zaznaczyć, że w Czechach odmiennie ukształtowano kompetencję Prezydenta odnośnie do powoływania sędziów. W przeciwieństwie do polskiego modelu konstytucyjnego uprawnienie do powoływania sędziów w Czechach nie stanowi prezydenckiej prerogatywy i zostało objęte obowiązkiem uzyskania kontrasygnaty. Nie stanowi więc absolutnej władzy Głowy Państwa. Stosownie do treści art. 63 ust. 1 lit. „i' czeskiej Konstytucji, Prezydent Republiki mianuje sędziów. Zgodnie jednak z art. 63 ust. 3 i 4 tego unormowania, decyzje Prezydenta Republiki wydane na podstawie ust. 1 i 2 , a więc także dotyczące powoływania sędziów, wymagają dla swej ważności podpisu przewodniczącego rządu (premiera) lub upoważnionego przez niego innego członka rządu. Przyjmuje się przy tym, że instytucja kontrasygnaty stanowi formę ograniczenia pozycji ustrojowej Prezydenta i tym samym ograniczenia jego władzy, wymuszając w pewnych kwestiach, w tym przypadku nominacji sędziowskiej, współdziałanie rządu i prezydenta. Z kolei, jeżeli określony akt Głowy Państwa został zwolniony z obowiązku uzy-

46 Ustawa Konstytucyjna Czeskiej Rady Narodowej z dnia 16 grudnia 1992 r. Konstytucja Republiki Czeskiej (Sbírka Zákonů České Republiky z 1993 r., nr 1 z 28 grudnia 1992, www.biblioteka.sejm. gov.pl (tłum. M. Kruk Jarosz).

47 M. Kruk, O trybie wyboru Prezydenta Republiki Czeskiej, w: Ustroje, tradycje i porównania. Ksiega jubileuszowa dedykowana prof. dr hab. Marianowi Grzybowskiemu w siedemdziesiąt a rocznicę urodzin, red. P. Mikula, A. Kulig, J. Karpa, G. Kuc, Warszawa 2015, s. 460.

48 Ustawa konstytucyjna nr 71/2012 Sb. oraz ustawa nr 275/2012 Sb. o wyborze Prezydenta Republiki i o zmianie niektórych ustaw (zákon o volbě prezidenta republiky).

49 P. Molek, Relacje między prezydentem..., s. 43. 
skania kontrasygnaty, oznacza to, że stanowi prezydencką prerogatywę, której istotę stanowi możliwość samodzielnego podejmowania przez prezydenta danego aktu, nawet wbrew woli innych organów państwa ${ }^{50}$. W modelu czeskim w praktyce Prezydentowi Republiki Czeskiej przedstawia się zwykle dwa razy do roku listę kandydatów na sędziów. Ponieważ powoływanie sędziów nie zostało wyłączone spod kontrasygnaty premiera lub upoważnionego ministra, lista kandydatów jest przekazywana także do akceptacji rządu. W świetle orzecznictwa czeskiego Najwyższego Sądu Administracyjnego w Brnie i doktryny przyjmuje się przy tym, że Prezydent może odmówić powołania sędziego tylko w wyjątkowych sytuacjach, a jego akt podlega kontroli sądu administracyjnego ${ }^{51}$.

\section{Wnioski końcowe}

W artykule przedstawiono w syntetycznej formie najważniejsze stanowiska doktrynalne i orzecznicze odnośnie do odmowy powołania przez Prezydenta do pełnienia urzędu na stanowisku sędziowskim. Na tym tle rysuje się szereg zagadnień problemowych, które starałem się zasygnalizować i samodzielnie ocenić.

W myśl art. 179 Konstytucji RP, sędziowie są powoływani przez RP, na wniosek KRS, na czas nieoznaczony. Zgodnie zaś z art. 144 ust. 2, akty urzędowe Prezydenta wymagają dla swojej ważności podpisu Prezesa Rady Ministrów, który przez podpisanie aktu ponosi odpowiedzialność przed Sejmem. Istotne przy tym jest zastrzeżenie zawarte $\mathrm{w}$ art. 144 ust. 3 Konstytucji RP, zgodnie z którym przepis ust. 2 nie dotyczy aktów wymienionych w punktach: 1-30. W art. 144 ust. 3 pkt 17 Konstytucji jest zaś mowa o powoływaniu sędziów. Prezydent może zatem wydać akt o powołaniu sędziego tylko na wniosek KRS i nie podlega on kontrasygnacie Prezesa Rady Ministrów.

Sądy administracyjne konsekwentnie utrzymują, że Prezydent RP nie jest w tego rodzaju sprawie organem administracji publicznej w rozumieniu kodeksu postępowania administracyjnego, w Kancelarii Prezydenta nie przeprowadza się postępowania administracyjnego w tym zakresie, a Głowa Państwa wykonuje swoje konstytucyjne kompetencje (prerogatywy), a więc z osobą zainteresowaną powołaniem na urząd sędziego ani z KRS nie łączy go stosunek administracyjnoprawny. W mojej ocenie nie są to całkowicie przekonujące argumenty. Co prawda za takim rozumieniem aktu Prezydenta przemawia jego wysoka pozycja ustrojowa, niemniej

\footnotetext{
50 L. Garlicki, Polskie prawo konstytucyjne, Warszawa 2012, s. 268.

51 M. Bobek, The Administration of Courts in the Czech Republic. In Search of Constitutional Balance, "European Public Law" 2010, nr 16, s. 260-263.
} 
jednak adresat postanowienia prezydenta, w którym ukształtowano jego prawo podmiotowe dostępu do służby publicznej, w tym przypadku służby sędziowskiej, powinien $\mathrm{w}$ ramach państwa prawnego mieć zagwarantowane prawo do sądowoadministracyjnej kontroli tego aktu. Na przykładzie czeskim wskazano, że tego typu spory są naturalnym zjawiskiem iskrzenia pomiędzy poszczególnymi segmentami władzy, niejednokrotnie przyznającymi sobie prawo do zachowania sfery władzy absolutnej, pozbawionej jakiejkolwiek, w tym sądowej, kontroli. Moim zdaniem tego typu mechanizmy powinny być stopniowo eliminowane z relacji obywateli (kandydatów na sędziego) z władzą państwową. Objęcie w przyszłości kognicją sądowoadministracyjną tego rodzaju aktów Głowy Państwa mogłoby z powodzeniem znaleźć swoje racjonalne uzasadnienie w ramach innych aktów i czynności z zakresu administracji dotyczących uprawnień lub obowiązków wynikających z przepisów prawa (art. $3 \S 2$ pkt. 4 p.p.s.a.). Przyjmuje się bowiem, że właśnie to unormowanie ma stanowić barierę przed unikaniem przez władzę państwową kontroli ze strony sądu administracyjnego ${ }^{52}$. W literaturze i poniekąd w orzecznictwie sądów administracyjnych funkcjonuje koncepcja, zgodnie z którą, gdy norma materialna wymaga autorytatywnej konkretyzacji, a przepisy prawa nie kształtują stosunku materialnego na podstawie innej formy, przyjmuje się domniemanie załatwienia sprawy administracyjnej $w$ formie decyzji. Dotyczy to sytuacji, gdy norma prawa materialnego stanowić będzie podstawę do wyprowadzenia uprawnienia lub obowiązku jednostki, a więc wówczas, gdy w grę wchodzi prawo podmiotowe jednostki, jak ma to miejsce w tym przypadku. Myślę, że podobna koncepcja mogłaby z powodzeniem znaleźć zastosowanie w orzecznictwie sądowoadministracyjnym odnośnie do postanowienia Prezydenta RP o odmowie powołania sędziów, wymagałoby to jednak zmiany wieloletniej, konsekwentnie utrzymywanej linii orzeczniczej sądów administracyjnych ${ }^{53}$.

Moim zdaniem nie jest zasadne kwestionowanie decyzyjnej roli Prezydenta $\mathrm{w}$ ramach procedury nominacyjnej. To, że ma on prawo do merytorycznej oceny wniosku, wynika wprost z ustawy o KRS, w świetle której Prezydent może wystąpić do Rady z wnioskiem o ponowne rozpatrzenie sprawy, wskazując na przeszkody do powołania sędziego. Trudne do zaakceptowania jest przy tym związanie Prezydenta RP wnioskiem KRS skierowanym po ponownym rozpoznaniu sprawy i sprowadzenie jego roli do czysto ceremonialnego zatwierdzenia wniosku tego

52 M. Kowalski, Prawo do sądu administracyjnego. Standard międzynarodowy i konstytucyjny oraz jego realizacja, Warszawa 2019, s. 452.

53 B. Adamiak, Prawo do procesu w świetle regulacji prawa procesowego administracyjnego, w: System prawa administracyjnego, tom 9, Prawo procesowe administracyjne, red. R. Hauser, Z. Niewiadomski, A. Wróbel, Warszawa 2010, s. 93-94. 
organu. Ewentualna odmowa powołania na stanowisko sędziowskie powinna mieć jednak charakter wyjątkowy i znajdować swoje uzasadnienie na płaszczyźnie konstytucyjnej. Prezydent powinien wskazać motywy swojej decyzji, co czyniłoby ten akt, przy całej jego arbitralności, bardziej transparentnym. Jest to istotne nie tylko z punktu widzenia samego zainteresowanego powołaniem na urząd sędziego, ale ma także ważny wymiar społeczny i osobisty, w aktualnym kształcie może bowiem naruszać dobra osobiste takiej osoby. W świetle aktualnego unormowania konstytucyjnego wydaje się, że Prezydent w istocie nie ma takiego obowiązku. Zmiana zwyczaju konstytucyjnego w tym zakresie mogłaby jednak stanowić wyraz dobrej praktyki konstytucyjnej.

\section{Bibliografia}

Adamiak B., Prawo do procesu w świetle regulacji prawa procesowego administracyjnego, w: System prawa administracyjnego, tom 9, Prawo procesowe administracyjne, red. R. Hauser, Z. Niewiadomski, A. Wróbel, Warszawa 2010.

Banaszak B., Konstytucja Rzeczypospolitej Polskiej. Komentarz, Warszawa 2009.

Bobek M., The Administration of Courts in the Czech Republic. In Search of Constitutional Balance, "European Public Law" 2010, nr 16.

Brzozowski W., Niezależność konstytucyjnego organu państwa i jej ochrona, Warszawa 2016. Ciapała J., Charakter kompetencji Prezydenta RP. Uwagi w kontekście kompetencji w zakresie powotywania sędziów, „Przegląd Sejmowy” 2008, nr 4(87).

Ereciński T., Gudowski J., Iwulski J., Prawo o ustroju sądów powszechnych, Ustawa o Krajowej Radzie Sąownictwa. Komentarz, red. J. Gudowski, Warszawa 2010.

Garlicki L., Komentarz do art. 179 Konstytucji RP, Tom IV, Warszawa 2005.

Garlicki L., Niezależność sądownictwa - powoływanie sędziów - nadrzędność konstytucji (kilka uwag nad ewolucja orzecznictwa Sądu Najwyższego w Indiach), w: Aktualne problemy konstytucji. Księga jubileuszowa z okazji 40-lecia pracy naukowej Profesora Bogustawa Banaszaka, red. H. Babiuch, P. Kapusta, J. Michalska, Legnica 2017.

Garlicki L., Polskie prawo konstytucyjne, Warszawa 2012.

Hauser R., Stosunek administracyjnoprawny, w: Instytucje prawa administracyjnego, red. R. Hauser, Z. Niewiadomski, A. Wróbel, C.H. Beck, Warszawa 2015.

Kowalski M., Nadużycie prawa do informacji publicznej, ZNSA 2016, nr 2(65).

Kowalski M., Prawo do sq̨u administracyjnego. Standard międzynarodowy i konstytucyjny oraz jego realizacja, Warszawa 2019.

Kowalski M., Terminy w postępowaniu administracyjnymi i sqdowoadministracyjnym, Wroclaw 2013.

Kuczyński T., Z problematyki postępowania w sprawie powołania sędziego sq̨du administracyjnego, w: Balicki R., M. Masternak-Kubiak (red.), W stużbie dobru wspólnemu. Księga jubileuszowa dedykowana Profesorowi Januszowi Trzcińskiemu, Warszawa 2012. 
Kruk M., O trybie wyboru Prezydenta Republiki Czeskiej, w: Ustroje, tradycje i porównania. Księga jubileuszowa dedykowana prof. dr hab. Marianowi Grzybowskiemu w siedemdziesiąt a rocznicę urodzin, red. P. Mikula, A. Kulig, J. Karpa, G. Kuc, Warszawa 2015.

Łabno A., Krajowa Rada Sądownictwa. Pozycja ustrojowa i możliwości reformy. Wybrane zagadnienia, w: Aktualne problemy konstytucji. Ksiega jubileuszowa z okazji 40-lecia pracy naukowej Profesora Bogustawa Banaszaka, red. H. Babiuch, P. Kapusta, J. Michalska, Legnica 2017.

Molek P., Relacje między prezydentem, a władza sadownicza w republice parlamentarnej, w: Sadownictwo administracyjne $w$ Polsce i Czechach (wybrane zagadnienia omawiane w ramach polsko-czeskiej wspótpracy sędziów sądów administracyjnych), Warszawa 2018.

Niewiadomski Z., Pojęcie administracji publicznej, w: Instytucje prawa administracyjnego, red. R. Hauser, Z. Niewiadomski, A. Wróbel, C.H. Beck, Warszawa 2015.

Piotrowski R., Sędziowie a władza wykonawcza. Wybrane problemy konstytucyjne, "Studia Iuridica" 2008, t. XLVIII.

Roztocil A., Orzecznictwo dotyczące aktów prezydenta w zakresie powolywania i odwotywania sędziów oraz sędziów funkcyjnych, w: Sądownictwo administracyjne w Polsce i Czechach (wybrane zagadnienia omawiane w ramach polsko-czeskiej wspótpracy sędziów sq̨dów administracyjnych), Warszawa 2018.

Sarnecki P., Nota 11 Komentarza do art. 144 Konstytucji RP, Tom IV, Warszawa 2005.

Sokolewicz W., Konstytucyjna regulacja władzy sądowniczej, w: Konstytucja, ustrój, system finansowy państwa. Księga pamiątkowa ku czci prof. Natalii Gail, Warszawa 1999.

Sułkowski J., Dokumenty - wyrok Najwyższego Sadu Administracyjnego w Brnie z dnia 27 kwietnia 2006 r., sygn. akt 4 Aps 3/2005 dotyczacy kognicji sądowoadministracyjnej odnośnie do kontroli legalności aktów Prezydenta Republiki Czeskiej w przedmiocie odmowy powołania na stanowisko sędziowskie, „Przegląd Sejmowy” 2008, nr 4.

Sułkowski J., Uprawnienia Prezydenta RP do powotywania sędziów, „Przegląd Sejmowy” 2008, nr 4.

Szmyt A., Wątpliwości wokót reform wymiaru sprawiedliwości, w: Ratio est anima legis. Księga Jubileuszowa ku czci Profesora Janusza Trzcińskiego, Warszawa 2007.

Szwast M., Prawo do odpowiedniego ukształtowania ustroju i pozycji organów wymiaru sprawiedliwości, rozprawa doktorska obroniona w 2017 r. na WPiA UW, niepublikowana.

Ziółkowski M., Prerogatywa Prezydenta RP do powotywania sędziów (uwagi o art. 144 ust. 3 pkt 17 i art. 179 Konstytucji), „Przegląd Sejmowy” 2013, nr 1. 